\title{
OPTIMALISASI FUNGSI PESANTREN SEBAGAI AGEN PENGEMBANGAN SDM PERSPEKTIF DAKWAH
}

\author{
Dedy Susanto \\ Fakultas Dakwah dan Komunikasi UIN Walisongo Semarang \\ (E-mail: dedyssosi@gmail.com)
}

\begin{abstract}
Pesantren as community development agents, are expected to prepare a number of concepts for developing students' resources, both for improving the quality of the boarding school and for improving the quality of community life. In order to carry out his da'wah as the realization of amar ma'ruf, pesantren does not only carry out preaching verbally only but needs to be developed with a model of da'wah in terms of empowering students. Robbi Rodliyya Pesantren is one of the social agents to make changes to the welfare of the people by adopting multimedia technology, but in the discourse in the community and students / students, they see that the use of internet media has a bad impact on children's development and affect their morals who tend to think negatively However, there needs to be an approach to change the mindset of the community and santri in relation to the use of modern media, therefore social engineering needs to be done.

Keywords: Da'wah, Community Empowerment, Social Engineering

Abstrak

Pesantren sebagai agen pengembangan masyarakat, sangat diharapkan mempersiapkan sejumlah konsep pengembangan sumber daya santri, baik untuk peningkatan kualitas Pondok pesantren itu maupun untuk peningkatan kualitas kehidupan masyarakat. Dalam rangka untuk melakanakan dakwahnya sebagai realisasi amar ma'ruf, pesantren tidak hanya melakukan dakwah secara lisan saja namun perlu dikembangkan dengan model dakwah bil hal dalam bentuk pemberdayaan terhadap santri. Pesantren Robbi Rodliyya merupakan salah satu agen sosial untuk melakukan perubahan kesejahteraan terhadap umat dengan mengadobsi teknologi multi media, namun dalam wacana di masyarakat dan santri/ siswa, mereka memandang bahwa penggunakan media internet membawa dampak yang buruk bagi perkembangan anak dan mempengaruhi akhlaknya yang cenderung berfikir negatif, namun hal tersebut perlu ada pendekatan untuk mengubah pola pikir masyarakat maupun santri terkait dengan penggunaan media modern, oleh karenanya perlu dilakukan social engineering.

Kata Kunci: Dakwah, Pemberdayaan Masyarakat, Rekayasa Sosial.
\end{abstract}




\section{A. Pendahuluan}

Dakwah pada hakekatnya adalah mengaktualisasikan nilai-nilai dan ajaran Islam ke dalam kehidupan sehari-hari, dalam lingkup pribadi, keluarga, dan masyarakat sehingga terwujudnya khairu ummah yang sejahtera lahir batin, bahagia dunia dan akhirat. Dakwah berarti proses penyelenggaraan dakwah baik dilakukan secara individu terlebih lagi secara kelompok melalui organisasi maupun lembaga dengan melalui langkah-langkah menetapkan sasaran, tujuan, bentuk kegiatan dan langkah-langkah sistematis dalam proses kegiatan, untuk mencapai tujuan dakwah itu sendiri secara optimal, efektif dan efesien.

Islam merupakan agama dakwah, di mana di dalamnya terdapat usaha menyebarluaskan kebenaran ajaran yang diyakini berasal dari Allah SWT, untuk disebarluaskan kepada semua manusia. Semangat menyebarluaskan kebenaran ini merupakan tugas suci dan wujud pengabdian kepada Tuhan. Melaksanakan dakwah (menegakkan amar ma'ruf nahi munkar) merupakan kewajiban semua umat Islam baik laki-laki maupun perempuan, baik dilakukan secara individu maupun berkelompok yang terorganisir. Menurut Tasmara ${ }^{1}$ bahwa secara teologis dakwah dianggap mission Sacre (proyek berpahala) dan kedudukan dakwah itu sendiri bersifat conditio sine quanon.

Dakwah dalam realita kerjanya mempunyai pola-pola strategi yang beraneka warna, di antara strategi dakwah yang digunakan oleh para da'i adalah dengan dakwah pemberdayaan masyarakat Islam. Pengembangan masyarakat Islam bertujuan untuk mengembangan potensi umat dari yang kurang baik menjadi baik dan lebih baik. Pengembangan tersebut juga memiliki jalannya masing-masing baik berupa pengembangan ekonomi kerakyatan, pengembangan keterampilan dan pengembangan ilmu pengetahuan sesuai dengan situasi dan kondisi masyarakat serta potensi yang dimiliki oleh seorang da'i.

Perkembangan ilmu pengetahuan dan teknologi serta dampak pembangunan dewasa ini, memberikan pengaruh kuat atas munculnya dua fenomena yang saling berlawanan, Disatu sisi orang semakin bersikap sekuler sementara disisi lain justru semakin bersifat agamis, bahkan cenderung sufistik atau fundamentalistik. Pesantren merupakan salah satu basis organisasi dakwah

\footnotetext{
${ }^{1}$ Toto Tasmara, Komunikasi Dakwah, (Jakarta: Media Pratam, 1997), h. 33
} 
yang mempunyai fungsi dalam pemberdayaan masyarakat Islam. Pesantren yang dulu memiliki kesan sebagai tempat untuk mengkaji kitab-kitab salafi saja yang terkesan sangat jauh dari teknologi dan perkembangan zaman mulai menampakkan fungsinya sebagai basis untuk pemberdayaan masyarakat dengan menyuguhkan pembelajaran yang berbasis multi media. Salah satu pondok pesantren di Kota Semarang yang berperan sebagai social engineering adalah pesantren Robi Rodhiya. Bagaimana gerak langkahnya dalam social engineering akan diuraikan dalam artikel ini.

\section{B. Landasar Teoritis}

\section{Pesantren, Dakwah Pemeberdayaan Masyarakat Islam dan Social}

\section{Engineering}

a. Pesantren dan Sumber Daya Santri

Manusia merupakan sumber daya penting dalam sebuah organisasi dan dalam hal ini khususnya sumber daya santri pada pesantren, sumber daya santri ini sangat menunjang dalam sebuah Pondok pesantren dengan karya, bakat, kreativitas dan dorongan. Betapapun sempurnanya aspek ilmu pengetahuan dan teknologi serta ekonomi, tanpa aspek manusia sulit kiranya tujuan-tujuan organisasi maupun Pondok pesantren dapat tercapai.

Dalam hal ini Pondok pesantren sebagai agen pengembangan masyarakat, sangat diharapkan mempersiapkan sejumlah konsep pengembangan sumber daya santri, baik untuk peningkatan kualitas Pondok pesantren itu maupun untuk peningkatan kualitas kehidupan masyarakat.

Sumber Daya Manusia dapat diklasifikasikan menjadi dua aspek yaitu kuantitas dan kualitas. Kuantitas menyangkut jumlah sumber daya manusia yang sangat penting kontribusinya. Sedangkan aspek kualitas menyangkut mutu dari sumber daya manusia yang berkaitan dengan kemampuan fisik maupun kemampuan non fisik (kecerdasan non mental). Yang menyangkut kemampuan bekerja, berfikir dan ketrampilan-ketrampilan lainnya. Akan tetapi antara kuantitas dan kualitas harus berjalan seimbang agar tercapai tujuan yang diinginkan. $^{2}$

${ }^{2}$ Munir dan Wahyu Ilaihi, Manajemen Dakwah, (Jakarta: Rahmat Semesta, 2006), h. 187. 
Pengembangan sumber daya manusia secara makro adalah penting untuk mencapai tujuan-tujuan pembangunan secara efektif. Pengembangan sumber daya manusia yang terarah dan terencana disertai pengelolaan yang baik akan dapat menghemat dana, atau setidak-tidaknya pengelolaan dan pemakaian dana dapat lebih efisien dan efektif. Demikian pula pengembangan sumber daya manusia di suatu pondok pesantren sangat penting untuk mencapai hasil kerja yang optimal. Dapat dikatakan, pengembangan sumber daya manusia merupakan sesuatu yang tidak boleh tidak harus ada dan terjadi di Pondok pesantren. Namun demikian dalam pelaksanaan pengembangan sumber daya manuasia ini, perlu mempertimbangkan faktor-faktor, baik dari pondok pesantren (internal) maupun dari luar (eksternal).

Faktor internal mencakup keseluruhan kehidupan Pondok pesantren yang dapat dikendalikan oleh pimpinan. Secara rinci faktor-faktor internal meliputi: Pertama, visi, misi, dan tujuan Pondok pesantren. Untuk memenuhi visi, misi dan tujuan diperlukan perencanaan yang baik serta implementasi pelaksanaan yang tepat. Pelaksanaan kegiatan atau program Pondok pesantren dalam upaya memenuhi visi, misi dan tujuan organisasi diperlukan kemampuan Sumber Daya Manusia, yang hanya bisa dicapai dengan pengembangan Sumber Daya Manusia di Pondok pesantren bersangkutan. Kedua, visi, misi dan tujuan pondok pesantren satu dengan yang lainnya mungkin memiliki kesamaan, namun strategi kesamaan untuk mencapai visi, misi dan tujuan tidak sama. Setiap pondok pesantren memiliki strategi tertentu. Untuk itu diperlukan kemampuan Pondok pesantren bersangkutan untuk mengantisipasi keadaan luar yang dapat membawa dampak bagi pondok pesantren tersebut.

Faktor eksternal yang merupakan lingkungan di mana pondok pesantren itu berada harus benar-benar diperhatikan. Faktor eksternal yang merupakan lingkungan di mana pondok pesantren itu berada harus benar-benar diperhitungkan. Faktor-faktor eksternal Pondok pesantren antara lain meliputi: Pertama, kebijakan pemerintah, baik yang dikeluarkan melalui perundanganundangan, peraturan pemerintah, surat keputusan menteri atau pejabat pemerintah dan sebagainya. Kebijaksanaan-kebijaksanaan merupakan arahan yang harus diperhitungkan yang sudah tentu akan mempengaruhi program pengembangan 
Sumber Daya Manusia dan pondok pesantren bersangkutan. Kedua, faktor sosial kultural di masyarakat yang berbeda tidak boleh diabaikan oleh pondok pesantren, karena pondok pesantren itu sendiri didirikan pada hakikatnya adalah untuk kepentingan masyarakat, sehingga dalam mengembangkan Sumber Daya Manusia Pondok pesantren mempertimbangkan faktor tersebut. Ketiga, perkembangan iptek di luar pondok pesantren yang sudah sedemikian pesat, harus mampu memilih iptek yang tepat untuk pondok pesantrennya. Demikian juga kemampuan kader-kader Pondok pesantren harus diadaptasikan dengan kondisi tersebut. ${ }^{3}$

b. Dakwah Pemberdayaan Masyarakat Islam

Kata dakwah secara etimologi berasal dari bahasa Arab da'a, yad'u, da'watan yangbermakna panggilan, seruan dan ajakan. Secara terminologi, kata dakwah banyak didefinisikan oleh para pakar ilmu dakwah, diantaranya sebagai berikut:

1) Ibnu Taimiyah

"Dakwah merupakan suatu proses usaha untuk mengajak agar orang beriman kepada Allah, percaya apa yang telah diberitakan oleh Rasul (dan taat terhadap apa yang telah diperintahkan, meliputi dua kalimat syahadat, menegakkan shalat, menunaikan zakat, puasa bulan ramadhan, melaksanakan haji), iman kepada malaikat, kitab-kitab-Nya, hari kebangkitan, qadha dan qadar. Selain itu mengajak agar hamba menyembah kepada Allah seakan-akan melihatnya."4

Ibnu Taimiyah dalam pengertian di atas nampaknya condong pada pemahaman dakwah sebagai suatu proses yang berkelanjutan dan ditujukan kepada masyarakat yang sudah mengenal Islam dan ajaran-ajarannya sekaligus mengajak mereka untuk beribadah kepada Allah dengan ikhlas untuk mencapai derajat ihsan.

2) al-Bahy al-Khauly

Dakwah adalah usaha mengubah situasi kepada yang lebih baik dan sempurna, baik terhadap individu maupun masyarakat. Dan barang siapa yang h. 7.

${ }^{3}$ Sunarto (eds), Manajemen Pesantren, Yogyakarta: Pustaka Pesantren, 2005),

${ }^{4}$ Taimiyah, Ibnu, Majmu' Al-Fatâwâ, Juz Xv, Cet. I, (Riyad: Mathabi' Al-Riyad, 1985), h. 185. 
meragukan terhadap seruan ini, maka sesungguhnya dia akan merugi. ${ }^{5}$ Pengertian tersebut tampaknya Al-Khauly lebih memandang esensi dakwah bukan hanya terletak pada usaha mengajak kepada keimanan dan ibadah saja, lebih dari itu dakwah adalah usaha penyadaran manusia atas keberadaan dan keadaan hidup mereka. Usaha penyadaran ini dilakukan pertama kali agar manusia melakukan introspeksi diri, baru untuk selanjutnya mereka diajak untuk memasuki kehidupan yang lebih baik dan sempurna, dengan melaksanakan seluruh ajaran Islam dalam seluruh dimensi kehidupannya. Barangkali yang dimaksud pengertian ini, sesuai dengan pendapat A. Munir Mulkhan, bahwa dakwah juga bermakna pemecahan suatu masalah dan pemenuhan kebutuhan manusia. ${ }^{6}$

\section{3) Ra'uf Syalaby}

Dakwah adalah gerakan untuk merealisasikan undang-undang Allah yang telah diturunkan kepada Nabi Muhammad Saw. ${ }^{7}$ Pengertian ini cukup singkat, tapi cukup jelas maknanya yaitu dakwah merupakan perjuangan untuk menegakkan agama tauhid, amar ma'rūf dan nahi munkar dan menjalankan syariat-syariat Islam lainnya.

\section{4) Ali Mahfuzh}

Ali Mahfuzh dalam bukunya Hidayah al-Mursyidin, memberikan definisi dakwah sebagai berikut: "Mendorong (memotivasi) ummat manusia melaksanakan kebaikan dan mengikuti petunjuk serta memerintah mereka berbuat makruf dan mencegahnya dari perbuatan mungkar agar mereka memperoleh kebahagiaan dunia dan akhirat. ${ }^{\prime 8}$ Berbeda dengan pendapat yang lain, tampaknya Ali Mahfudz lebih cenderung mengartikan dakwah sebagai aktivitas untuk memberikan motivasi kepada umat manusia agar melaksanakan kebaikan dan mengikuti petunjuk. Dalam hal ini Ali Mahfuzh juga mengartikan dakwah sebagai usaha menegakkan amar ma'rūf dan nahi munkar dengan tujuan menyelamatkan umat manusia agar mencapai kebahagiaan di dunia dan akhirat.

${ }^{5}$ Al-Khauly, Al-Bahy, Tadzkirât Al-Du'ât, Cet. Ke-8, (Kairo: Maktabah Dâr AlTuras, 1987), h. 35. 1996), h. 205

Mulkhan, Abdul Munir, Ideologisasi Gerakan Dakwah, (Yogyakarta: Si Press,

${ }_{7}$ Syalaby, Ra'uf, 1985, Al-Da'wah Al-Islâmiyah Fî 'Ahdihâ Al-Makky: Manâhijuhâ Wa Ghayatuhâ, (Kairo: Al-Fajr Al-Jadîd, 1985), h. 34.

h. 7 .

${ }^{8}$ Mahfudz, Syekh Ali, Hidâyat Al-Mursyidîn, Cet. Vii, (Mesir: Dâr Al-Mishr, 1975), 
5) H.S.M. Nasaruddin Latif

Nasaruddin Latif dalam bukunya Teori dan Praktek Da'wah Islamiyah, mendefinisikan dakwah sebagai: "Setiap usaha atau aktivitas dengan lisan atau tulisan dan lainnya, yang bersifat menyeru, mengajak, memanggil manusia lainnya untuk beriman dan mentaati Allah SWT, sesuai dengan garis-garis aqidah dan syari'at serta akhlak Islamiyah"9 (Latif, 1971: 11). Dari pengertian tersebut di atas, Nasaruddin Latif memfokuskan pada cara atau metode untuk berdakwah, yaitu dengan lisan atau tulisan, yang tujuannya adalah membawa manusia ke arah yang telah digariskan Allah.

6) Thomas W Arnold

Thomas W Arnold dalam bukunya The Preacing of Islam mendefinisikan agama dakwah sebagai:

“Agama yang di dalamnya berusaha menyebarluaskan kebenaran dan mengajak orang-orang yang belum mempercayainya, dianggap sebagai tugas suci oleh pendirinya atau oleh para penggantinya..... Semangat memperjuangkan kebenaran agama itulah yang tak kunjung padam dari jiwa para pengikutnya sehingga kebenaran itu terwujud dalam fikiran, kata-kata dan perbuatan, semangat yang membuat mereka merasa tidak puas sampai berhasil menanamkan nilai kebenaran itu ke dalam jiwa setiap orang sehingga apa yang diyakini sebagai kebenaran diterima oleh seluruh manusia."10

Beberapa pengertian dakwah tersebut di muka, meskipun dituangkan dalam bahasa dan kalimat yang berbeda, akan tetapi kandungan isinya tetap sama, di mana dakwah dipahami sebagai seruan, ajakan dan panggilan dalam rangka membangun masyarakat Islam berdasarkan kebenaran ajaran Islam yang hakiki. Definisi-definisi tersebut di atas dapat ditarik kesimpulan, bahwa: pertama, dakwah merupakan sebuah proses usaha yang dilakukan secara sadar dan sengaja, sehingga diperlukan organisasi, manajemen, sistem, metode dan media yang tepat. Kedua, usaha yang diselenggarakan itu berupa: ajakan kepada manusia untuk beriman dan mematuhi ketentuan-ketentuan Allah, amar ma'rūf dalam arti

\footnotetext{
1971), h. 11

${ }^{\text {io }}$ Arnold, Thomas W., The Preaching of Islam, A History of the Propagation of the Muslim Faith, (Delhi: Low Price Publication, 1995), h. 1.
}

${ }^{9}$ Latif, Nasaruddin, Teori \& Praktek Da'wah Islamiyah, (Jakarta: Firma Dara, 
perbaikan dan pembangunan masyarakat, dan nahi munkar. Ketiga, proses usaha yang diselenggarakan tersebut adalah berdasarkan suatu tujuan tertentu, yaitu kebahagiaan dan kesejahteraan hidup yang diridlai Allah.

Secara etimologi pemberdayaan berasal dari kata dasar "daya" yang artinya kekuatan dan kemampuan. Berangkat dari pemahaman tersebut, maka pemberdayaan dapat dimaknai sebagai suatu proses untuk memperoleh daya/ kekuatan/ kemampuan atau proses pemberian daya/ kekuatan/ kemampuan dari pihak yang memiliki daya kepada pihak yang kurang atau belum berdaya. Kata "memperoleh" menurut Sulistiyani dalam Kemitraan dan Model-Model Pemberdayaan mengindikasikan bahwa yang menjadi sumber inisiatif untuk berdaya berasal dari masyarakat atau individu itu sendiri ${ }^{11}$ (Sulistiyani, 2004: 77). Melihat apa yang dikatakan Sulistiyani tersebut di atas, bahwa peran pemberdayaan adalah juga menumbuhkembangkan sebuah potensi yang dimiliki pada tiap-tiap individu atau masyarakat.

Pemberdayaan sebagai upaya memberikan kontribusi pada aktualisasi potensi tertinggi kehidupan manusia. Pemberdayaan selayaknya ditujukan untuk mencapai sebuah standar kehidupan ekonomi yang menjamin pemenuhan kebutuhan manusia. Hal ini merupakan sebuah tahapan yang esensial dan fundamental menuju tercapainya tujuan kesejahteraan manusia. Kebutuhan dasar tidak dilihat dalam batasan-batasan minimum manusia yaitu kebutuhan akan makanan, tempat tinggal, pakaian dan kesehatan, tetapi juga sebagai kebutuhan akan rasa aman, kasih sayang, mendapatkan penghormatan dan kesempatan untuk bekerja secara fair, serta tentu saja aktualisasi spiritual. ${ }^{12}$

Konsepsi pembedayaan dalam konteks Pengembangan Masyarakat Islam agaknya cukup relevan dalam hal ini. Beberapa asumsi yang dapat digunakan dalam rangka mewujudkan semangat ini adalah sebagai berikut: Pertama, pada intinya upaya-upaya pemberdayaan masyarakat dapat dilihat sebagai peletakan sebuah tatanan sosial dimana manusia secara adil dan terbuka dapat melakukan usahanya sebagai perwujudan atas kemampuan dan potensi yang dimilikinya

11 Sulistiyani, Ambar Teguh, Kemitraan dan Model-Model Pemberdayaan, (Yogyakarta: Gava Media, 2004), h. 77

${ }^{12}$ Supriyati Istiqomah, Pemberdayaan dalam Konteks Pengembangan Masyarakat Islam, (Jurnal Volume 4 No 1, 2008), h. 68. 
sehingga kebutuhannya (material dan spiritual) dapat terpenuhi. Pemberdayaan masyarakat, oleh karena itu, tidak berwujud tawaran sebuah proyek usaha kepada masyarakat, tetapi sebuah pembenahan struktur sosial yang mengedepankan keadilan. Pemberdayaan masyarakat pada dasarnya merencanakan dan menyiapkan suatu perubahan sosial yang berarti bagi peningkatan kualitas kehidupan manusia.

Kedua, Pemberdayaan masyarakat tidak dilihat sebagai suatu proses pemberian dari pihak yang memiliki sesuatu kepada pihak yang tidak memiliki. Kerangka pemahaman ini akan menjerumuskan kepada usaha-usaha yang sekadar memberikan kesenangan sesaat dan bersifat tambal sulam. Misalnya, pemberian bantuan dana segar (fresh money) kepada masyarakat hanya akan mengakibatkan hilangnya kemandirian dalam masyarakat tersebut atau timbulnya ketergantungan. Akibat yang lebih buruk adalah tumbuhnya mental "meminta". Padahal, dalam Islam, meminta itu tingkatannya beberapa derajat lebih rendah dari pada memberi.

Ketiga, pemberdayaan masyarakat mesti dilihat sebagai sebuah proses pembelajaran kepada masyarakat agar mereka dapat secara mandiri melakukan upaya-upaya perbaikan kualitas kehidupannya. Menurut Soedjatmoko, ada suatu proses yang seringkali dilupakan bahwa pembangunan adalah social learning. Oleh karena itu, pemberdayaan masyarakat sesungguhnya merupakan sebuah proses kolektif dimana kehidupan berkeluarga, bertetangga, dan bernegara tidak sekadar menyiapkan penyesuaian-penyesuaian terhadap perubahan sosial yang mereka lalui, tetapi secara aktif mengarahkan perubahan tersebut pada terpenuhinya kebutuhan besama.

Keempat, pemberdayaan masyarakat, tidak mungkin dilaksanakan tanpa keterlibatan secara penuh oleh masyarakat itu sendiri. Partisipasi bukan sekadar diartikan sebagai kehadiran mereka untuk mengikuti suatu kegiatan, melainkan dipahami sebagai kontribusi mereka dalam setiap tahapan yang mesti dilalui oleh suatu program kerja pemberdayaan masyarakat, terutama dalam tahapan perumusan kebutuhan yang mesti dipenuhi. Asumsinya, masyarakatlah yang paling tahu kebutuhan dan permasalahan yang mereka hadapi.

Kelima, pemberdayaan masyarakat merupakan suatu upaya pengembangan masyarakat. Tidak mungkin rasanya tuntutan akan keterlibatan masyarakat dalam 
suatu program pembangunan tatkala masyarakat itu sendiri tidak memiliki daya ataupun bekal yang cukup. Oleh karena itu, mesti ada suatu mekanisme dan sistem untuk memberdayakan masyarakat. Masyarakat harus diberi suatu kepercayaan bahwa tanpa ada keterlibatan mereka secara penuh, perbaikan kualitas kehidupan mereka tidak akan membawa hasil yang berarti. Memang, sering kali people empowerment diawali dengan mengubah dahulu cara pandang masyarakat dari nrimo ing pandum menjadi aktif partisipatif. ${ }^{13}$

c. Rekayasa Sosial (Social Engineering)

Rekayasa sosial merupakan campur tangan atau seni memanipulasi sebuah gerakan ilmiah dari visi ideal tertentu yang ditujukan untuk mempengaruhi perubahan sosial, bisa berupa kebaikan maupun keburukan dan juga bisa berupa kejujuran, bisa pula berupa kebohongan. Perubahan sosial yang dilakukan karena munculnya problem-problem sosial sebagai adanya perbedaan antara das sollen (yang seharusnya) dengan das sein (yang nyata). Tindakan kolektif untuk memecahkan masalah sosial (collective action to solve social problems). Biasanya ditandai dengan perubahan bentuk dan fungsionalisasi kelompok, lembaga atau tatanan sosial yang penting.

Dibanding dengan perencanaan sosial (social planning), ia lebih luas atau lebih pragmatis, sebab sebuah rekayasa selalu mengandung perencanaan, tetapi tidak semua perencanaan diimplementasikan hingga terimplementasikan di alam nyata. Begitu pula jika dibandingkan dengan manajemen perubahan (change management), ia memiliki makna lebih pasti, sebab jika obyek dari manajemen dapat ditafsirkan sebagai perubahan dalam arti luas, sedangkan obyek dari rekayasa sosial sudah jelas, yakni perubahan sosial menuju suatu tatanan dan sistem baru sesuai dengan apa yang dikehendaki sang perekayasa ${ }^{14}$ (Praja, 2007: $45)$.

Strategi-Strategi Perubahan Sosial menurut Rahmat (2007: 43) bahwa perubahan sosial dapat dilakukan dengan Strategi Normative-Reeducative (normatif-reedukatif); Normative merupakan kata sifat dari norm yang berarti

\footnotetext{
${ }^{13}$ Mudzakir, M. Djauzi, Teori dan Praktek Pengembangan Masyarakat, Surabaya: Usaha Nasional, 1986), h. 12-15.

${ }^{14}$ Praja, Juhaya S, Teori Hukum dan Aplikasinya, (Cv. Pustaka Karya, 2000), h. 45 .
} 
aturan yang berlaku di masyarakat (norma sosial), sementara reeducation dimaknai sebagai pendidikan ulang untuk menanamkan dan mengganti paradigma berpikir masyarakat yang lama dengan yang baru. Sifat strategi perubahannya perlahan dan bertahap.Cara atau taktik yang digunakan adalah mendidik, yakni bukan saja mengubah perilaku yang tampak melainkan juga mengubah keyakinan dan nilai sasaran perubahan.

Strategi perubahan sosial yang lain adalah Persuasive Strategy (strategi persuasif); Strategi ini dijalankan melalui pembentukan opini dan pandangan masyarakat, biasanya menggunakan media massa dan propaganda. Cara atau taktik yang digunakan adalah membujuk, yakni berusaha menimbulkan perubahan perilaku yang dikehendaki para sasaran perubahan dengan mengidentifikasikan objek sosial pada kepercayaan atau nilai agen perubahan. Bahasa merupakan media utamanya. Efektifitas teori persuasi sangat bergantung pada media yang dipergunakan. Media itu dibagi dua; (1) media pengaruh (media komunikasi yang digunakan pelaku perubahan untuk mencegah sasaran perubahan), dan (2) media respon (media yang digunakan oleh sasaran perubahan dalam menggulingkan tanggapan mereka), keduanya dapat menggunakan media massa atau saluransaluran interpersonal.

Dan yang terakhir adalah People's power (revolusi); Merupakan bagian dari power strategy (strategi perubahan sosial dengan kekuasaan), revolusi ini merupakan puncak dari semua bentuk perubahan sosial, karena ia menyentuh segenap sudut dan dimensi sosial secara radikal, massal, cepat, dan mengundang gejolak intelektual dan emosional dari semua orang yang terlibat di dalamnya. Cara atau taktik yang digunakan berbentuk paksaan (memaksa) dengan kekuasaan, yakni upaya menimbulkan kepasrahan behavoral atau kerjasama pada sasaran perubahan melalui penggunaan sanksi yang dikendalikan agen.

\section{Hasil Penelitian dan Analisis}

Pondok pesantren merupakan sebagai agen pengembangan masyarakat, sangat diharapkan mempersiapkan sejumlah konsep pengembangan sumber daya santri, baik untuk peningkatan kualitas Pondok pesantren itu maupun untuk peningkatan kualitas kehidupan masyarakat. Hal tersebut sudah diaplikasikan oleh pondok pesantren Robbi Rodliyya yang dalam pelaksanaan pendidikannya tidak 
hanya berkutik pada ilmu-ilmu agama tetapi juga pada ilmu-ilmu aplikatif yang berguna untuk kehidupan masyarakat.

Pondok pesantren Robbi Rodliyya terletak di Jalan Woltermonginsidi no 59 Kelurahan Banjardowo Kecamatan Genuk Kota Semarang. Dalam hal ini pondok pesantren Robbi Rodliyya sebagai agen pengembangan masyarakat, dan oleh para ustadz dalam hal ini adalah ustadz Faqih, mereka mempunyai harapan untuk mempersiapkan sejumlah konsep pengembangan sumber daya santri, baik untuk peningkatan kualitas pondok pesantren itu maupun untuk peningkatan kualitas kehidupan masyarakat.

Pondok pesantren Robbi Rodliyya mempunyai sebuah impian untuk mencetak insan-insan bertakwa yang handal di bidang teknologi informasi dan multimedia. Dengan adanya impian yang dimiliki maka menjadi cikal bakal berdirinya SMK-IT (Sekolah Menengah Kejuruan Teknologi Informasi) Robbi Rodliyya Semarang sebagai upaya sebagai dakwah pemberdayaan masyarakat. Kehadiran SMK TI di pondok pesantren Robbi Rodliyya memberikan warna baru ditengah masyarakat. Tidak hanya dalam mengelola teknologi informasi dan multimedia yang tawarkan melainkan kualitas siswa yang memiliki kepribadian Islami juga menjadi ciri khas dari lulusan SMK TI Robbi Rodliyya. Sehingga kekhawatiran masyarakat akan penyalahgunaan teknologi informasi saat ini mampu terjawab dengan hadirnya SMK TI Robbi Rodliyya.

Rekayasa sosial menurut Jalaludin rahmad merupakan merubah sesuatu keadaan masyarakat sesuai dengan apa yang diharapkan. Dalam proses perubahan sosial terdapat sebab perubahan dalam arti tujuan sosial yang diharapkan, adanya pelaku perubahan, terdapat sasaran perubahan, adanya saluran perubahan dan strategi perubahan. Perkembangan teknologi informasi terutama yang berkaitan dengan penggunaan internet memberikan wacana dominan kepada masyarakat, bahwa penggunaan teknologi tersebut memberikan dampak yang sangat negatif terhadap perkembangan anak, hal ini terbukti dengan hadirnya internet menjadikan pergaulan bebas yang merajalela, pornografi yang menyebabkan hubungan sex bebas, tak jarang ditemui anak-anak SMA melakukan perbuatan mesum di warnet. Pola pikir masyarakat yang demikian merupakan problem masyarakat yang harus direkayasa oleh agen perubahan yaitu para ustadz, dalam hal ini ustadz Faqih sebagai agen perubahan terhadap problem sosial kaitannya dengan pola pikir yang salah.

Wacana yang berkembang tersebut menjadikan orang tua tidak menginginkan anaknya menggunakan internet, sebagai pernyataan bapak Slamet bahwa: 
"Kulo kuatir karo sing jenenge internet seng wis akeh neng daerah kene, kabeh wong tuwo kudu njogo anake ojo sampek nggunakake internet mergo iso ndadeake akibet seng elek neng anak, buktine onone internet okeh anak SMA seng nglakoni mesum lan akeng anak seng hubungan lanang wedok sak karepe dewe" Saya sangat kuatir dengan kehadiran internet yang berkembang di masyarakat, kita harus menjaga anak kita jangan sampai menggunakan teknologi internet karena dapat memberikan dampak yang buruk kepada anak, buktinya dengan internet, anak-anak SMA melakukan perilaku mesum dan tidak sedikit melakukan sex bebas" (Slamet, 13/ 8/ 2014). ${ }^{15}$

Opini masyarakat yang berkembang di Kelurahan Banjardowo menjadikan pondok pesantren Robbi Rodliyya sebagai organisasi dan ustadz Faqih sebagai agen perubahan melakukan rekayasa sosial (Social Engineering) dengan mensosialisasikan visi-misinya untuk melakukan perubahan opini masyarakat, yaitu: Visi yang dimiliki adalah menjadi SMK terkemuka dalam membangun generasi berakhlaq mulia yang diridloi Allah yang memiliki keunggulan di bidang teknologi dan kepemimpinan. Sedangkan misinya adalah pertama, membangun Sistem Pendidikan yang komprehensif yang menyiapkan lulusannya untuk menjadi generasi muslim yang mempunyai landasan aqidah yang lurus (saliimul 'aqidah), ibadah yang benar (shahiihul 'ibadah) dan berakhlak mulia (matiinul khuluuq).

Kedua, Menumbuhkan semangat untuk menguasai dan memiliki kompetensi di bidang ilmu \& teknologi dan siap bersaing di dunia industri maupun wirausaha. Ketiga, Menumbuhkan sikap dan jiwa kepemimpinan, kemandirian dan kepekaan sosial dalam integritas pribadi yang tangguh. Keempat, Mengembangkan sistem berfikir yang dapat menumbuhkan kreativitas, keunggulan dan prestasi baik di lingkungan sekolah maupun di masyarakat. Kelima, Membangun jaringan (network) dengan Perusahaan, Instansi dan Perguruan Tinggi sehingga lulusannya diakui di dunia industri dan instansi pemerintah serta mudah untuk melanjutkan studi ke Perguruan Tinggi. Hal tersebut sesuai dengan apa yang diungkapkan Rahmad, bahwa Rekayasa sosial merupakan campur tangan atau seni memanipulasi sebuah gerakan ilmiah dari visi ideal tertentu yang ditujukan untuk mempengaruhi perubahan sosial, bisa berupa

\footnotetext{
${ }^{15}$ Slamet, Wawancara Pribadi, 19/8/2014
} 
kebaikan maupun keburukan dan juga bisa berupa kejujuran, bisa pula berupa kebohongan. ${ }^{16}$ Dan dalam hal ini pondok pesantren Robbi Rodliyya memberikan opini dan pengaruh kepada masyarakat ke arah yang positif.

Melalui perubahan opini dalam masyarakat, pesantren Robbi Rodliyya melakukan Strategi Perubahan Sosial, menurut Rahmat ${ }^{17}$ bahwa perubahan sosial dapat dilakukan dengan Strategi Normative-Reeducative (normatif-reedukatif); Normative merupakan kata sifat dari norm yang berarti aturan yang berlaku di masyarakat (norma sosial), sementara reeducation dimaknai sebagai pendidikan ulang untuk menanamkan dan mengganti paradigma berpikir masyarakat yang lama dengan yang baru.

Selain dengan strategi normative reedicative dan strategi persuasif, pondok pesantren Robbi Rodliyya juga melakukan strategi People's power (revolusi); Merupakan bagian dari power strategy (strategi perubahan sosial dengan kekuasaan), revolusi ini merupakan puncak dari semua bentuk perubahan sosial, karena ia menyentuh segenap sudut dan dimensi sosial secara radikal, massal, cepat, dan mengundang gejolak intelektual dan emosional dari semua orang yang terlibat di dalamnya khususnya bagi santri/ siswa. Cara atau taktik yang digunakan berbentuk paksaan (memaksa) dengan kekuasaan, yakni upaya menimbulkan kepasrahan behavoral atau kerjasama pada sasaran perubahan melalui penggunaan sanksi yang dikendalikan agen.

Pondok pesantren Robbi Rodliyya melakukan pendidikan yang sangat intensif terhadap para santri maupun siswa agar dalam penggunaan media internet dapat digunakan untuk hal-hal yang positif. Di antara pembinaan akhlak yang dilakukan oleh para ustadz adalah pertama, setiap pagi menjelang proses pembelajaran para ustadz memberikan energi positif kepada santri dengan memutar lantunan ayat al-qur'an (murotal) dari jam 06.30 -07.00 WIB. Dengan mendengarkan ayat-ayat suci al-Qur'an memberikan dampak yang positif terhadap siswa yang akan melakukan proses belajar-belajar. Kedua, melakukan mujahadah dengan membaca al-asma' al-husna dan do'a bersama dengan harapan di dalam belajar mengajar santri/ siswa mendapat bimbingan dari Allah

${ }^{16}$ Rakhmat, Jalaluddin, Rekayasa Sosial Reformasi, Revolusi, atau Manusia Besar, (Bandung: PT. Remaja Rosda Karya, 2000), h. 43

${ }_{17}$ Rakhmat, Jalaluddin, Rekayasa...., h. 44. 
SWT dan dalam penggunaan media internet dapat dipergunakan dengan sebaikbaiknya. Ketiga, melakukan sholat dhuha bersama baik ustadz maupun siswa. Dalam hal ini salah satu siswa mengumumkan kepada teman-teman yang masih berada di kelas maupun di lapangan untuk segera mengambil air wudhu guna melaksanakan sholat dhuha sebagai manifestasi kepasrahan kepada Allah dan mempunyai sebuah cita-cita yang mulia terkait dengan ilmu yang didapatkan. ${ }^{18}$ (Observasi, 12-15 / 9/2014).

Hal tersebut di atas sesuai dengan keteranga Badriyah, salah seorang alumni pondok pesantren/ SMK Robbi Rodliyya bahwa beliau memberikan keterangannya terkait dengan usaha pondok pesantren dalam menggembleng para siswa untuk menuju kepada akhlak yang mulia:

“Alhamdulillah saya sebagai alumni SMK Robbi Rodliyya merasa senang mendapatkan ilmu di sana karena dengan adanya penggemblengan akhlak yang mulia, walaupun teman-teman menggunakan teknologi multimedia/ internet, mereka tetap menggunakan teknologi tersebut untuk hal-hal yang positif. Dan teman-teman dapat mengubah mainset masyarakat bahwa yang dulunya internet dianggap sebagai hal yang sangat ditakuti menjadikan masyarakat mempunyai pikiran yang positif terhadap pemanfaatan media tersebut" ${ }^{\prime 19}$ (Badriyah, 24/ 9/2014).

Perubahan sosial yang dilakukan oleh pesantren Robbi Rodliyya memberikan dampak yang positif terhadap perkembangan pola pikir terhadap penggunaan media internet baik bagi para santri maupun masyarakat sekitar. Dengan usaha-usaha yang dilakukan maka memberikan pemahaman dan baik terhadap penggunaan media dan yang tak kalah pentingnya para ustadz menjalin saluran hubungan dengan perusahaan-perusahaan lain untuk membuka peluang kerja bagi para santri.

Dakwah merupakan suatu proses usaha untuk mengajak agar orang beriman kepada Allah, percaya apa yang telah diberitakan oleh Rasul (dan taat terhadap apa yang telah diperintahkan, meliputi dua kalimat syahadat, menegakkan shalat, menunaikan zakat, puasa bulan ramadhan, melaksanakan haji), iman kepada malaikat, kitab-kitab-Nya, hari kebangkitan, qadha dan qadar. Selain itu mengajak agar hamba menyembah kepada Allah seakan-akan

\footnotetext{
${ }^{18}$ Observasi,12-15/9/2014

${ }^{19}$ Badriyah, Wawancara Peribadi, 24/ 9/ 2014).
} 
melihatnya." 20 Dalam kegiatan dakwah pondok pesantren Robbi Rodliyya sudah memenuhi ke enam dari unsur dakwah, di antaranya dai, mad'u, maddah, thoriqoh, media, dan atsar.

Da'i dalam hal ini adalah bapak ustadz Ahmad Faqih selaku kepala sekolah dan kepala pondok serta para guru yang mengampu. Mad'u dalam hal ini adalah para santri dan siswa dari pondok pesantren dan SMK Robbi Rodliyya. Maddah dalam hal ini adalah seluruh pembelajaran keagamaan yang bersifat formal dan nonformal serta kurikulum yang berbasis pengetahuan umum dan teknologi. Thoriqoh dalam hal ini adalah metode pembelajaran para pengasuh dan guru yang meluputi bil hall, bil qolam, dan bil lisan. Media dalam hal ini adalah seluruh peralatan yang mendukung yang digunakan untuk proses transformasi pengembangan sumber daya santri. Dan atsar dalam hal ini adalah perubahan yang ada para santri yang meliputi emosional, spiritual dan intelektual.

\section{Kesimpulan}

Dakwah dalam realita kerjanya mempunyai pola-pola strategi yang beraneka warna, di antara strategi dakwah yang digunakan oleh para da'i adalah dengan dakwah pemberdayaan masyarakat Islam. Pengembangan masyarakat Islam bertujuan untuk mengembangan potensi umat dari yang kurang baik menjadi baik dan lebih baik. Pengembangan tersebut juga memiliki jalannya masing-masing baik berupa pengembangan ekonomi kerakyatan, pengembangan keterampilan dan pengembangan ilmu pengetahuan sesuai dengan situasi dan kondisi masyarakat serta potensi yang dimiliki oleh seorang da'i. Pesantren Robbi Rodliyya merupakan salah satu agen sosial dalam melakukan rekayasa sosial dengan mengadobsi keterampilan di bidang multi media, namun di tengah-tengah masyarakat dan santri, mereka mempunyai pemahaman yang kurang positif dengan kehadiran teknologi modern karena dalam wacarana dominan teknologi internet sering digunakan untuk hal-hal yang negatif, oleh karena itu pesantren Robbi Rodliyya melakukan social engineering untuk mengubah pola pikir santri dan masyarakat dengan berbagai strateginya sehingga dapat mengubah pola pikir dan perilaku penggunakan media modern.

${ }^{20}$ Taimiyah, Ibnu, Majmu' Al-Fatâwâ, Juz Xv, Cet. I, (Riyad: Mathabi' Al-Riyad, 1985) h. 185. 


\section{Daftar Pustaka}

Al-Khauly, Al-Bahy, 1987, Tadzkirât Al-Du'ât , Cet. Ke-8Kairo: Maktabah Dâr Al-Turas.

Arnold, Thomas W., 1995, The Preaching of Islam, A History of the Propagation of the Muslim Faith, Delhi: Low Price Publication.

Latif, Nasaruddin, , 1971, Teori \& Praktek Da'wah Islamiyah, Jakarta: Firma Dara.

Mahfudz, Syekh Ali, 1975, Hidâyat Al-Mursyidîn, Cet. Vii, Mesir: Dâr Al-Mishr.

Mulkhan, Abdul Munir, 1996, Ideologisasi Gerakan Dakwah, Yogyakarta: Si Press.

Munir dan Wahyu Ilaihi, 2006, Manajemen Dakwah, Jakarta: Rahmat Semesta.

Mudzakir, M. Djauzi , 1986, Teori dan Praktek Pengembangan Masyarakat, Surabaya: Usaha Nasional.

Praja, Juhaya S, 2000, Teori Hukum dan Aplikasinya,Cv.Pustaka Karya.

Rakhmat, Jalaluddin, 2000, Rekayasa Sosial Reformasi, Revolusi, atau Manusia Besar, bandung: PT.Remaja Rosda karaya.

Sunarto (eds), 2005, Manajemen Pesantren, Yogyakarta: Pustaka Pesantren.

Supriyati Istiqomah, 2008, Pemberdayaan dalam Konteks Pengembangan Masyarakat Islam, Jurnal Volume 4 no 1 tahun 2008).

Sulistiyani, Ambar Teguh, 2004, Kemitraan dan Model-Model Pemberdayaan, Yogyakarta: Gava Media.

Syalaby, Ra'uf, 1985, Al-Da'wah Al-Islâmiyah Fî̀ 'Ahdihâ Al-Makky: Manâhijuhâ Wa Ghayatuhâ, Kairo: Al-Fajr Al-Jadîd.

Taimiyah, Ibnu, 1985, Majmu’ Al-Fatâwâ, Juz Xv, Cet. I, Riyad: Mathabi' AlRiyad,.

Toto Tasmara, 1997, Komunikasi Dakwah, , Jakarta: Media Pratam.

Wawancara Bapak Slamet 19/8/2014

Wawancara Sdri Badriyah, 24/ 9/2014).

Observasi, 12-15/9/2014 